\title{
PROSES BERPIKIR PESERTA DIDIK DALAM PEMECAHAN SOAL CERITA MATEMATIKA DITINJAU DARI GAYA KOGNITIF
}

\author{
Econ Kabiran $^{1}$, Theresia Laurens ${ }^{2}$, Johannis Takaria ${ }^{3}$ \\ ${ }^{1,2,3}$ Program Studi Magister Pendidikan Matematika, Pascasarjana, Universitas Pattimura \\ Jalan Ir. M. Putuhena, Kampus Unpatti, Poka, Ambon, Indonesia \\ e-mail: 1econkabiran@gmail.com
}

\begin{abstract}
Abstrak
Penelitian ini bertujuan untuk mendeskripsikan proses berpikir peserta didik dalam pemecahan soal cerita matematika materi segitiga dan segiempat ditinjau dari gaya kognitif. Proses berpikir dalam penelitian ini adalah langkah-langkah yang dilakukan oleh peserta didik dengan melibatkan aktivitas mental dalam menyelesaikan persoalan yang berhubungan dengan pemecahan masalah. Proses berpikir dalam penelitian ini ada tiga macam yaitu proses berpikir konseptual, proses berpikir semi konseptual dan proses berpikir komputasional. Penelitian ini merupakan penelitian deskriptif kualitatif. Subjek dalam penelitian ini adalah peserta didik kelas VII yang terdiri dari empat peserta didik dengan rincian masing-masing dua peserta didik dari gaya kognitif Field Independent (FI) dan dua peserta didik dari gaya kognitif Field Dependent (FD). Teknik pengumpulan data yang digunakan adalah tes matematika dan wawancara. Data hasil tes matematika dan wawancara dianalisis berdasarkan indikator-indikator yang memenuhi proses berpikir konseptual, proses berpikir semi konseptual dan proses komputasional. Dari hasil analisis data diperoleh bahwa Proses berpikir peserta didik dalam pemecahan soal cerita matematika pada kelompok Field Independent cenderung bertipe proses berpikir konseptual dan semi konseptual. Dan proses berpikir peserta didik dalam pemecahan soal cerita pada kelompok Field Dependent cenderung bertipe proses berpikir semi konseptual dan komputasional.
\end{abstract}

Kata Kunci: proses berpikir, pemecahan soal cerita, gaya kognitif

\section{THE THINKING PROCESS OF STUDENTS IN SOLVING THE PROBLEM OF MATHEMATICAL STORIES VIEWED FROM COGNITIVE STYLE}

\begin{abstract}
This study aims to describe the thinking process of students in solving mathematical problems of triangular and quadrilateral material in terms of cognitive style. The thinking process in this study is the steps taken by students involving mental activities in solving problems related to problem solving. The process of thinking in this study there are three kinds, namely conceptual thinking, semi-conceptual thinking and computational thinking. This research is a qualitative descriptive study. The subjects in this study were grade VII students consisting of four students with details of each two students from the Field Independent (FI) cognitive style and two students from the Field Dependent cognitive style (FD). Data collection techniques used in this study were mathematical tests and interviews. Data on the results of mathematical tests and interviews were analyzed based on indicators suitable with the conceptual thinking process, semiconceptual thinking process and computational thinking process. From the results of data analysis, it was found that the students' thinking processes in solving mathematical story problems in the Field Independent group is the conceptual and semi-conceptual thinking processes. And students' thinking processes in solving mathematical story problems in the Field Dependent group tend to be semi-conceptual and computational thinking processes.
\end{abstract}

Keywords: thinking process, mathematical problem solving, cognitive style 


\section{Pendahuluan}

Proses berpikir peserta didik dalam menyelesaikan masalah matematika sebenarnya sangat penting bagi guru. Mengetahui proses berpikir peserta didik, memungkinkan guru memahami cara berpikir peserta didik dalam mengolah informasi yang diterima sambil mengarahkan peserta didik untuk mengubah cara pikirnya jika itu diperlukan, agar pembelajaran yang direncanakan dapat mencapai tujuan pembelajaran dan hasil yang maksimal. Selain itu, dengan mengetahui proses berpikir peserta didik, guru dapat melacak letak dan jenis kesalahan yang dilakukan oleh peserta didik.

Zuhri (1998) mengungkapkan bahwa proses berpikir dibedakan menjadi tiga yaitu proses berpikir konseptual, proses berpikir semikonseptual dan proses berpikir komputasional. Proses berpikir konseptual adalah cara berpikir yang selalu memecahkan suatu masalah menggunakan konsep yang telah dimilki berdasarkan hasil penilaiannya selama ini. Proses berpikir semikonseptual adalah cara berpikir yang selalu memecahkan suatu masalah menggunakan konsep tapi kurang memahami konsep tersebut sehingga cara penyelesaiannya dicampur dengan cara penyelesaian menggunakan intuisi. Sedangkan proses berpikir komputasional adalah cara berpikir yang pada umumnya dalam memecahkan suatu masalah cenderung menggunakan intuisi dan tidak menggunakan konsep.

Proses berpikir peserta didik yang berbedabeda tersebut dapat diamati apabila pembelajaran dipusatkan pada peserta didik, namun ketika pembelajaran yang dilakukan terpusat pada guru tanpa memperhatikan keadaan peserta didiknya, tentu saja pembelajaran yang dilaksanakan tidak berjalan dengan baik. Kemungkinan peserta didik yang dapat menerima pelajaran dengan baik hanya beberapa orang saja. Nilai yang tersebar tidak merata sehingga rata-rata hasil belajarnya masih rendah. Perolehan hasil belajar ini juga sering dikarenakan peserta didik mengalami kesulitan dalam pemecahan masalah matematika.

Pemecahan masalah merupakan cara yang tepat dalam pembelajaran untuk melatih peserta didik berpikir dan hal ini sudah dibuktikan para ahli melalui sejumlah penelitian. Pehkonen
(Ngilawajan, 2013) menyatakan bahwa "problem solving has generally been accepted as means for advancing thinking skills.", yang berarti bahwa pemecahan masalah telah diterima secara umum sebagai cara untuk meningkatkan keahlian berpikir. Someren (1994) juga menyatakan bahwa pemecahan masalah melibatkan proses berpikir dan usaha penuh. Hal ini terlihat jelas saat peserta didik menyelesaikan masalah matematika yang diberikan oleh guru seperti soal cerita matematika.

Proses berpikir peserta didik tidak semuanya sama antara yang satu dengan yang lainnya. Perbedaan tersebut bisa dibedakan berdasarkan banyak hal salah satunya adalah kemampuan mereka dalam menerima dan memproses informasi yang telah diberikan guru ketika pelajaran telah berlangsung. Kemampuan ini dikenal dengan gaya kognitif. Gaya kognitif ini sangat erat hubungannya dengan proses berpikir dan pemecahan masalah. Metode pengajaran yang dilakukan oleh guru akan sangat efektif sekali jika disesuaikan dengan gaya kognitif peserta didik.

Nasution (2011) mengungkapkan bahwa gaya kognitif dibedakan menjadi dua yaitu Field Dependent (FD) dan Field Independent (FI). Gaya kognitif FI adalah gaya yang dimiliki peserta didik yang cenderung menyatakan suatu gambarang lepas dari latar belakang gambaran tersebut, dan mampu membedakan objek-objek dari konteks sebenarnya. Sedangkan gaya kognitif FD adalah suatu gaya yang dimiliki peserta didik yang menerima sesuatu lebih secara global dan mengalami kesulitan untuk memisahkan diri dari keadaan sekitarnya atau lebih dipengaruhi lingkungan. Perbedaan proses berpikir peserta didik FI dan peserta didik FD akan terlihat ketika mereka menyelesaikan soal-soal matematika yang bersifat analitis dan terstruktur. Oleh karena itu, seorang guru dituntut untuk dapat mengetahui tipe gaya kognitif peserta didiknya.

Berdasarkan observasi awal di MTs. Negeri Ambon menunjukkan pentingnya proses berpikir peserta didik dan soal cerita bangun datar segitiga dan segiempat yang dianggap sulit bagi peserta didik SMP/MTs, maka penulis tertarik untuk meneliti "Proses Berpikir Peserta didik dalam Memecahkan Soal Cerita Matematika Ditinjau Dari Gaya Kognitif".

Berdasarkan uraian di atas, rumusan masalah penelitian ini adalah Bagaimana proses 
berpikir peserta didik SMP/MTs dengan gaya Kognitif dalam memecahkan soal cerita matematika?

\section{Metode Penelitian}

Penelitian ini menggunakan data kualitatif dan mendeskripsikan data untuk menghasilkan gambaran proses berpikir peserta didik dalam memecahkan soal cerita matematika peserta didik yang berbeda gaya kognitifnya. Proses berpikir tersebut terungkap melalui hasil karya peserta didik dalam menyelesaikan soal cerita matematika yang diamati melalui hasil karya tertulis dan diperkuat dengan wawancara. Subjek dalam penelitian ini adalah siswa kelas VII-8 MTs. Negeri Ambon tahun ajaran 2018/2019 yang berjumlah 36 siswa. Penetapan subjek penelitian didasari oleh beberapa pertimbangan yaitu: 1) peserta didik kelas VII sudah mendapat materi ajar
Segitiga dan Segiempat, 2) berdasar pada hasil tes gaya kognitif, 3) peserta didik kelas VII sudah mampu berkomunikasi lisan serta mampu mengungkapkan pendapat, sehingga diharapkan lebih mudah diwawancarai untuk memperoleh data akurat yang dibutuhkan pada penelitian ini.

Untuk mengumpulkan data digunakan tes dan wawancara. Tes yang dilakukan dalam penelitian ini adalah Group Embedded Figures Test (GEFT) dan tes pemecahan masalah. Wawancara yang digunakan adalah wawancara tidak terstruktur, untuk memverifikasi hasil jawaban tes pemecahan masalah kemudian dianalisis sehinggan tergambar proses berpikir peserta didik dalam pemecahan soal cerita matematika ditinjau dari gaya kognitif. Teknik analisis data dalam penelitian ini menggunakan reduksi data, penyajian data, dan penarikan kesimpulan.

Tabel 1. Indikator proses berpikir peserta didik dalam pemecahan masalah

\begin{tabular}{cl}
\hline Proses Berpikir & \multicolumn{1}{c}{ Indikator Proses Berpikir } \\
& Mampu menyatakan apa yang diketahui dalam soal dengan bahasa sendiri \\
& atau mengubah dalam kalimat matematika (B1.1) \\
& Mampu menyatakan apa yang ditanya dalam soal dengan bahasa sendiri \\
Konseptual & atau mengubah dalam kalimat matematika (B1.2) \\
& Membuat rencana penyelesaian dengan lengkap (B1.3) \\
& Mampu menyatakan langkah-langkah yang ditempuh dalam menyelesaikan \\
& soal menggunakan konsep yang pernah dipelajari (B1.4) \\
& Mampu memperbaiki jawaban (B1.5) \\
\hline \multirow{5}{*}{ Semi } & Kurang mampu menyatakan apa yang diketahui dalam soal dengan bahasa \\
& sendiri atau mengubah dalam kalimat matematika (B2.1) \\
& Kurang mampu menyatakan apa yang ditanya dalam soal dengan bahasa \\
& sendiri atau mengubah dalam kalimat matematika (B2.2) \\
& Membuat rencana penyelesaian, tetapi tidak lengkap (B2.3) \\
& Kurang mampu menyatakan langkah-langkah yang ditempuh dalam \\
& menyelesaikan soal menggunakan konsep yang pernah dipelajari (B2.4) \\
& Kurang mampu memperbaiki jawaban (B2.5) \\
\hline & Tidak mampu menyatakan apa yang diketahui dalam soal dengan bahasa \\
& sendiri atau mengubah dalam kalimat matematika (B3.1) \\
& Tidak mampu menyatakan apa yang ditanya dalam soal dengan bahasa \\
& sendiri atau mengubah dalam kalimat matematika (B3.2) \\
& Tidak membuat rencana penyelesaian (B3.3) \\
& Tidak mampu menyatakan langkah-langkah yang ditempuh dalam \\
& menyelesaikan soal menggunakan konsep yang pernah dipelajari (B3.4) \\
& Tidak mampu memperbaiki jawaban (B3.5) \\
\hline Komputasional &
\end{tabular}

(Zuhri, 1998)

\section{Hasil dan Pembahasan}

Pada tahap pelaksanaan, peserta didik diberikan tes GEFT agar dapat dikelompokkan ke dalam dua kelompok, yaitu peserta didik Field
Independent dan Field Dependent. Setelah mengetahui gaya kognitif peserta didik, kemudian diberikan tes pemecahan masalah kepada seluruh subjek penelitian. Dari hasil tes, kemudian 
dianalisis dan diklasifikasikan berdasarkan indikator proses berpikir.

\section{Deskripsi Proses Berpikir Peserta Didik dalam Pemecahan Soal Cerita Kelompok Gaya Kognitif Field Independent}

\subsection{Subjek S1 dalam Pemecahan Soal Cerita}

Indikator proses berpikir dalam pemecahan masalah pertama untuk konseptual adalah Mampu menyatakan apa yang diketahui dalam soal dengan bahasa sendiri atau mengubah dalam kalimat matematika (B1.1), subjek S1 pada bagian ini mampu menyatakan apa yang diketahui. Hasil wawancara subjek S1 menjelaskan "Yang diketahui dari soal luas persegi panjang $300 \mathrm{~m} 2$, perbandingan panjang dan lebar 4:3, 5 susun kawat yang ingin dipasang dan kawat yang tersedia 500 $\mathrm{m}$ ", dari respon tersebut terlihat bahwa subjek S1 mampu menyatakan apa yang diketahui dalam soal dengan bahasa sendiri.

Subjek S1 mampu menyatakan apa yang ditanya dari soal. Ini memenuhi indikator berikut dari proses berpikir konseptual yaitu mampu menyatakan apa yang ditanya dalam soal dengan bahasa sendiri atau mengubah dalam kalimat matematika (B1.2). Pada indikator ini subjek S1 mengerti apa yang ditanya dari soal seperti tanggapannya pada wawancara yaitu " kalau yang ditanya, cukupkah kawat berduri $500 \mathrm{~m}$ tersebut?". Petikan wawancara tersebut menunjukkan bahwa subjek S1 mampu menyatakan apa yang ditanya dalam soal dengan bahasa sendiri.

Selanjutnya, subjek S1 mampu membuat rencana penyelesaian dengan lengkap, hal ini ditunjukkan dengan penjelasan subjek S1 yang menyatakan bahwa "pertama-tama karena yang diketahui perbandingan maka rencananya akan mencari panjang dan lebar terlebih dahulu. Setelah itu, mencari keliling dan terakhir menentukan panjang kawat". Berdasarkan petikan wawancara tersebut tampak bahwa subjek S1 memenuhi indikator proses berpikir konseptual yaitu B1.4.

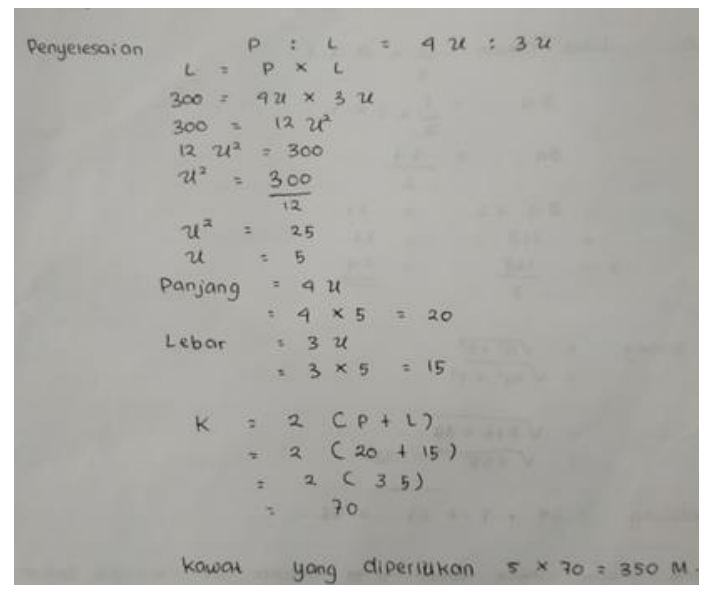

Subjek S1 mampu menyatakan langkahlangkah yang ditempuh dalam menyelesaikan soal menggunakan konsep yang pernah dipelajari, terlihat dari hasil kerja subjek S1 di atas bahwa subjek S1 menggunakan konsep yang telah dipelajari sebelumnya dengan baik dan mampu menyelesaikan soal yang diberikan langkah per langkah. Selain itu, subjek S1 juga mengecek kembali hasil kerjanya. Berdasarkan hasil wawancara subjek S1 menjelaskan "mulai dari rumus luas hingga panjang dan lebar dilihat kembali, panjang dan lebar yang telah diperoleh dikalikan untuk mengetahui apakah sudah sesuai dengan luas yang diketahui, setelah itu memeriksa hasil keliling dan memastikan sudah tepat atau belum secara keseluruhan".

Dengan demikian, Subjek S1 dengan gaya kognitif field Independent mempunyai tipe proses berpikir konseptual dalam pemecahan soal cerita karena dari hasil kerjanya menunjukkan subjek mampu mengungkapkan dengan kalimat sendiri apa yang diketahui (B1.1) dan apa yang ditanya (B1.2) dalam soal. Mampu membuat rencana dan menyebutkan konsep yang dipakai dalam menyelesaikan soal cerita (B1.3), dan yang terakhir mampu menyelesaikan soal cerita dengan baik menggunakan konsep yang telah ada (B1.4 dan B1.5).

\subsection{Subjek S1 dalam Pemecahan Soal Cerita}

Subjek S2 merupakan subjek dengan gaya kognitif field indepent, jika dilihat dari hasil kerjanya subjek S2 dapat mengerjakan soal yang diberikan dengan cukup baik. Pada bagian diketahui, subjek S2 menuliskan apa yang diketahui dari soal namun tidak keseluruhan dari apa yang diketahui. Hal tersebut terlihat dari hasil kerja S2, dimana S2 tidak menuliskan banyak susunan kawat yang dikehendaki dan berapa panjang kawat yang telah dibeli.

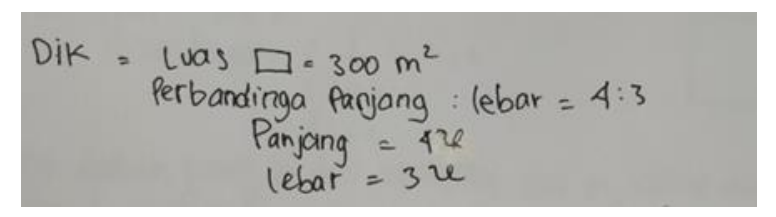

Dari hasil tersebut di atas menunjukkan bahwa subjek S2 kurang mampu menyatakan apa yang diketahui dalam soal dengan bahasa sendiri atau mengubah dalam kalimat matematika (B2.1). Begitu juga dengan bagian yang ditanya subjek S2 kurang mampu menyatakan apa yang ditanya dalam soal dengan bahasa sendiri atau mengubah dalam kalimat matematika (B2.2). Subjek S2 menyatakan "yang ditanya itu cukupkah kawat berduri tersebut?". Hal ini menunjukkan ketidaksempurnaan pertanyaan karena tidak disebutkan panjang kawat duri yang tersedia. 
Selanjutnya, pada bagian perencanaan subjek S2 hanya merencanakan untuk mencari panjang dan lebar dari persegi panjang. Hasil petikan wawancara terhadap subjek S2, yaitu "agak bingung tapi rencana awal yang dicari panjang dan lebar karena sudah diketahui perbandingannya". Dengan demikian, subjek S2 mampu mebuat rencana penyelesaian tetapi tidak lengkap (B2.3) sehingga berdampak pada langkahlangkah penyelesaiannya.

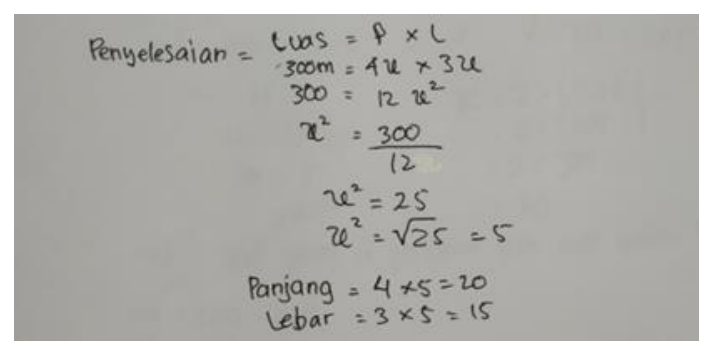

Subjek S2 mampu menentukan panjang dan lebar namun ada penulisan yang tidak sesuai pada penyelesaian soal tersebut. Pada langkah selanjutnya, menunjukkan subjek S2 belum mampu memahami masalah pada soal sehingga S2 tidak menggunakan konsep yang pernah dipelajari sebelumnya melainkan menggunakan intuisinya sendiri. Dari hasil wawancara subjek S2 menyatakan "setelah mendapatkan panjang dan lebar, langkah selanjutnya mengalikan panjang kawat dengan banyak susunan kawat yaitu 5 kemudian dikalikan lagi dengan 5". Dan ketika ditanya lebih lanjut oleh peneliti terkait alasan subjek menyelesaikan dengan cara tersebut, subjek S2 menjawab "karena menurut saya mengalikan panjang 20 dengan 5 itu akan mendapatkan panjang kawat untuk 1 susun". Hal ini menunjukkan bahwa S2 kurang mampu menyatakan langkah-langkah yang ditempuh dalam menyelesaikan soal menggunakan konsep yang pernah dipelajari (B2.4) dan kurang mampu memperbaiki jawaban (B2.5).

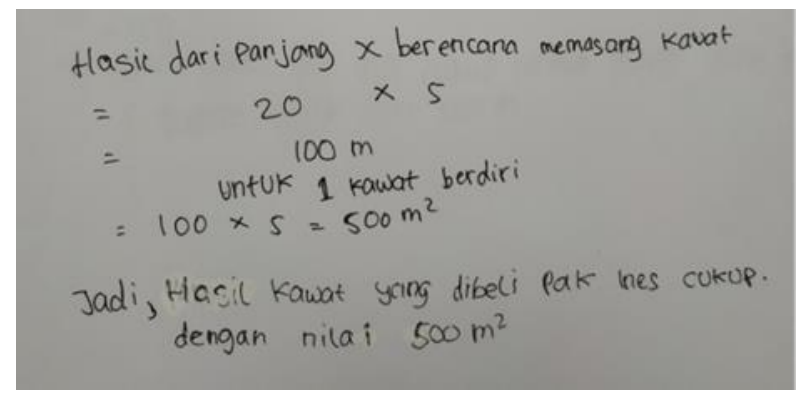

Berdasarkan deskripsi tersebut Subjek S2 dengan gaya kognitif field Independent mempunyai tipe proses berpikir semi konseptual dalam pemecahan soal cerita karena dari hasil kerjanya menunjukkan subjek kurang mampu mengungkapkan apa yang diketahui seluruhnya dari soal tersebut dengan kalimat sendiri (B2.1) dan begitu juga dengan apa yang ditanya (B2.2). Mampu menyebutkan konsep yang dipakai dalam menyelesaikan soal cerita namun tidak lengkap (B2.3) sehingga hasil yang diperoleh belum benar, dan yang terakhir mampu menjelaskan langkahlangkah yang harus ditempuh dalam penyelesaian namun belum lengkap serta belum mampu memperbaiki jawaban yang keliru (B2.4 dan B2.5).

Tabel 2. Proses berpikir dalam memecahkan soal cerita kelompok field independent

\begin{tabular}{|c|c|}
\hline $\begin{array}{c}\text { Karakteristik Proses } \\
\text { Berpikir }\end{array}$ & $\begin{array}{c}\text { Aktivitas Proses } \\
\text { berpikir }\end{array}$ \\
\hline $\begin{array}{l}\text { Mampu mengungkapkan } \\
\text { dengan } \\
\text { kalimat sendiri apa yang } \\
\text { diketahui dan apa yang } \\
\text { ditanya dalam soal }\end{array}$ & $\begin{array}{l}\text { Peserta didik } \\
\text { menyebutkan apa yang } \\
\text { diketahui dan ditanya } \\
\text { dalam soal serta siswa } \\
\text { mampu merubah unsur- } \\
\text { unsur yang perlu untuk } \\
\text { dirubah. }\end{array}$ \\
\hline $\begin{array}{l}\text { Cenderung } \\
\text { menggunakan } \\
\text { konsep yang sudah } \\
\text { dipelajari }\end{array}$ & $\begin{array}{ll}\text { Peserta didik } & \text { mampu } \\
\text { memakai } & \text { konsep- } \\
\text { konsep } & \\
\text { yang sudah } & \text { dipelajari } \\
\text { sebelumnya. } & \end{array}$ \\
\hline $\begin{array}{l}\text { Mampu menjelaskan } \\
\text { langkah-langkah } \\
\text { yang ditempuh }\end{array}$ & $\begin{array}{l}\text { Peserta didik mampu } \\
\text { memberikan penjelasan } \\
\text { tetang langkah-langkah } \\
\text { yang ditempuh dalam } \\
\text { memecahkan masalah. } \\
\text { Sehingga, siswa } \\
\text { mampu memberikan } \\
\text { kesimpulan sesuai } \\
\text { permintaan soal }\end{array}$ \\
\hline
\end{tabular}

\section{Deskripsi Proses Berpikir Peserta Didik dalam Pemecahan Soal Cerita Kelompok Gaya Kognitif Field Dependent}

\subsection{Subjek S3 dalam Pemecahan Soal Cerita}

Subjek S3 merupakan salah satu peserta didik dengan gaya kognitif Field Dependent. Dari hasil penyelesaian soal yang diberikan, subjek S3 mencoba memahami maksud dari soal yang diberikan dan menentukan apa yang diketahui. Namun, subjek belum mampu menyatakan dengan lengkap apa yang diketahui dari soal. Hal itu ditunjukkan dengan penjelasan subjek yang menyatakan bahwa "pertama kali membaca soal, saya sangat bingung tapi saya mencoba membaca kembali dan menuliskan yang diketahui yaitu luas $300 \mathrm{~m} 2$ dan perbandingan panjang dan lebar 4:3". Dari petikan wawancara tersebut terlihat bahwa subjek S3 kurang mampu menyatakan apa yang diketahui dalam soal dengan bahasa sendiri atau mengubah dalam kalimat matematika (B2.1). 
Selanjutnya, subjek S3 menuliskan apa yang ditanya dengan singkat, tidak ada keterangan jelas pada apa yang ditanya. Berdasarkan wawancara, subjek S3 menjelaskan "yang ditanya itu juga sedikit bingung mau menuliskan apa, karena kalimatnya cukup panjang. Jadi saya tulis cukup atau tidak". Ini menunjukkan subjek S3 dengan gaya kognitif field dependent kurang mampu menyatakan apa yang ditanya dalam soal dengan bahasa sendiri atau mengubah dalam kalimat matematika (B2.2). Selanjutnya, subjek S3 belum mampu merencanakan tahapan penyelesaian dengan lengkap. Subjek S3 menjelaskan "bingung, tapi saya pikirkan pertama kali adalah menentukan keliling persegi panjang karena telah diketahui panjang dan lebar". Subjek S3 mengalami sedikit kesulitan dalam memahami soal sehingga mengganggap bahwa panjang dan lebar telah diketahui pada soal. Subjek S3 gagal memahami bahwa yang dimaksud pada soal adalah perbandingan panjang dan lebar. Pada dasarnya, Subjek S3 mampu mebuat rencana penyelesaian tetapi tidak lengkap (B2.3).

Pada tahapan penyelesaian, subjek S3 melewati salah satu tahapan untuk menentukan panjang dan lebar. S3 menyelesaikan soal dengan menggunakan rumus keliling tanpa mencari terlebih dahulu panjang dan lebar. Dari petikan wawancara dengan subjek S3 menjelaskan bahwa "langkah pertama mencari keliling, dan diperoleh keliling $14 \mathrm{~m}$, kemudian dikalikan 5 sehingga diperoleh panjang kawat yang dibutuhkan $70 \mathrm{~m}$ ". Peneliti kemudian menanyakan kepada subjek S3 "apakah yakin dengan setiap langkah yang dibuat?". Subjek S3 mengabaikan luas yang diketahui pada soal dan mengandalkan pemikirannya saja tanpa didasari konsep yang pernah dipelajari sebelumnya. Subjek menggunakan konsep untuk menyelesaikan keliling persegi panjang, namun hasil yang diperoleh keliru karena mengabaikan konsep yang seharusnya didahulukan. Subjek S3 juga kurang mampu dalam memeriksa kembali hasil pekerjaannya sehingga jawaban yang keliru tidak dapat diperbaiki. Hal ini ditunjukkan dengan penjelasan subjek yang menyatakan bahwa "iya yakin, karena kawat berduri yang akan dipasang hanya pada bagian keliling sehingga rumus yang digunakan adalah keliling persegi panjang”. Berdasarkan petikan wawancara tersebut terlihat bahwa subjek S3 kurang mampu menyatakan langkah-langkah yang ditempuh dalam menyelesaikan soal menggunakan konsep yang pernah dipelajari (B2.4) dan kurang mampu memperbaiki jawaban (B2.5).

Dengan demikian, Subjek S3 dengan gaya kognitif field dependent mempunyai tipe proses berpikir semi konseptual dalam pemecahan soal cerita karena dari hasil kerjanya menunjukkan subjek kurang mampu mengungkapkan dengan kalimat sendiri apa yang diketahui dan apa yang ditanya dalam soal (B2.1 dan B2.2). Kurang mampu menyebutkan konsep yang dipakai dalam menyelesaikan soal cerita (B2.3), dan yang terakhir subjek mampu menjelaskan langkah-langkah yang harus ditempuh dalam penyelesaian namun karena salah dalam merumuskan langkah mengakibatkan hasil penyelesaian keliru dan subjek belum mampu memperbaiki jawaban yang keliru tersebut (B2.4 dan B2.5).

\subsection{Subjek S4 dalam Pemecahan Soal Cerita}

Berdasarkan hasil tes pemecahan masalah, subjek S4 dengan gaya kognitif field Dependent tidak menyatakan apa yang diketahui dan ditanya dari soal.

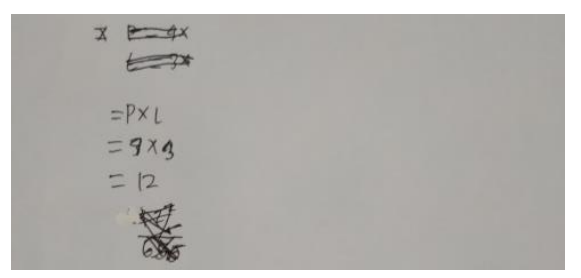

Hasil wawancara dengan subjek S4 diketahui bahwa subjek tidak membuat rencana penyelesaian. Subjek mencoba menyelesaikan soal yang diberikan dengan mengandalkan intuisi tanpa menggunakan konsep yang pernah dipelajari sebelumnya.

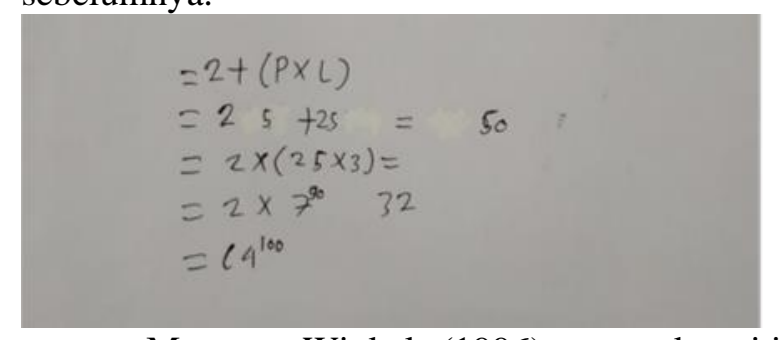

Menurut Winkel (1996), gaya kognitif field dependent cenderung bergantung pada medan. Sama halnya dalam penyelesaian soal matematika, peserta didik dengan gaya kognitif field dependent cenderung bergantung pada contoh yang diberikan, sehingga bila diminta menyelesaikan soal tanpa contoh atau subjek telah lupa dengan contoh yang pernah diberikan maka subjek akan mengalami kesulitan dalam menyelesaikan soal pemecahan masalah yang diberikan. Subjek S4 juga tidak mampu menyebutkan konsep yang berkaitan dengan soal yang diberikan dan tidak mampu mengerjakan langkah per langkah dengan tepat, bahkan penulisan rumusnya juga keliru. Bahkan Subjek S3 tidak mampu memperbaiki jawaban yang telah dibuat dan tidak mampu menarik kesimpulan.

Dari deskripsi di atas, dapat disimpulkan Subjek S4 dengan gaya kognitif field dependent 
mempunyai tipe proses berpikir komputasional dalam pemecahan soal cerita karena dari hasil kerjanya menunjukkan subjek tidak mampu mengungkapkan dengan kalimat sendiri apa yang diketahui dan apa yang ditanya dari soal (B3.1 dan 3.2). Subjek tidak mampu membuat rencana dan menyebutkan konsep yang dipakai dalam menyelesaikan soal cerita (B3.3), dan yang terakhir tidak mampu menjelaskan langkah-langkah yang ditempuh dalam penyelesaian sehingga hasil pekerjaan tidak tepat dan tidak mampu memperbaiki jawaban (B3.4 dan B3.5).

Tabel 3. Proses berpikir dalam memecahkan soal cerita kelompok field Dependent

\begin{tabular}{ll}
\multicolumn{1}{c}{ Karakteristik Proses } & \multicolumn{1}{c}{$\begin{array}{c}\text { Aktivitas Proses } \\
\text { berpikir }\end{array}$} \\
\hline $\begin{array}{l}\text { Mampu mengungkapkan } \\
\text { dengan kalimat sendiri } \\
\text { apa yang diketahui dan } \\
\text { apa yang ditanya dalam } \\
\text { soal }\end{array}$ & $\begin{array}{l}\text { Peserta didik } \\
\text { cenderung kurang } \\
\text { mampu atau tidak } \\
\text { menyebutkan apa yang } \\
\text { diketahui dan ditanya } \\
\text { dalam soal. }\end{array}$ \\
\hline Cenderung & Peserta didik kurang \\
menggunakan konsep & mampu memakai \\
yang sudah dipelajari & konsep-konsep yang \\
& sudah dipelajari \\
& sebelumnya. \\
\hline Mampu menjelaskan & Peserta didik kurang \\
manpu memberikan \\
& penjelasan tentang \\
& langkah-langkah yang \\
& ditempuh dalam \\
memecahkan masalah. & Sehingga, siswa tidak \\
& mampu memberikan \\
& kesimpulan sesuai \\
& permintaan soal \\
\hline
\end{tabular}

Proses berpikir peserta didik dengan gaya kognitif field independent dalam pemecahan soal matematika cenderung lebih baik jika dibandingkan dengan peserta didik gaya kognitif field dependent. Hal ini sejalan dengan pendapat Ratumanan (2003) yang menyatakan bahwa orang yang FI cenderung tertarik pada matematika dan sains, sedangkan orang yang FD cenderung menyukai pelajaran sastra dan sejarah. Peserta didik FI lebih mampu dalam analisis dan menyelesaikan masalah dengan caranya sendiri, sedangkan peserta didik FD lebih bergantung pada contoh yang diajarkan dan dapat mengalami kesulitan dalam penyelesaian jika soal diubah dengan kalimat yang berbeda

\section{Kesimpulan}

Berdasarkan deskripsi dan analisis data yang dilakukan peneliti, maka dapat disimpulkan beberapa hal berikut: a. Proses berpikir peserta didik kelas VII MTsN Ambon dalam pemecahan soal cerita matematika pada kelompok Field Independent cenderung bertipe proses berpikir konseptual dan semi konseptual.

b. Proses berpikir peserta didik kelas VII MTsN Ambon dalam pemecahan soal cerita matematika pada kelompok Field Dependent cenderung bertipe proses berpikir semi konseptual dan komputasional.

Berdasarkan kesimpulan di atas, dapat dikemukakan saran kepada para pendidik lebih mengenali tipe proses berpikir peserta didik selama pembelajaran terutama dalam pemecahan soal cerita matematika dan tidak mengabaikan gaya kognitif dimiliki peserta didik. Sementara, subjek dalam penelitian ini hanya terbatas pada peserta didik MTsN Ambon, sehingga hasil yang diperoleh hanya berlaku pada subjek tersebut, maka disarankan bagi peneliti yang lain untuk memperbesar jumlah subjek agar hasil yang diperoleh berlaku di daerah yang lebih luas

\section{Daftar Pustaka}

Marpaung, Y. (1986). Proses Berpikir Siswa dalam Pembentukan Konsep Algoritma Matematis. Makalah Pidato Dies Natalies XXXI IKIP Sanata Dharma Yogyakarta, 25 Oktober 1986.

Moleong, Lexy J. (2017). Metode Penelitian Kualitatif. Bandung: Remaja Rosdakarya.

Nasution, S. 2011. Berbagai Pendekatan dalam Proses Belajar Mengajar. Jakarta: Bumi Aksara.

Ngilawajan, Darma Andreas. (2013). Proses Berpikir Siswa SMA dalam Memecahkan Masalah Matematika Materi Turunan Ditinjau Dari Gaya Kognitif Field Independent dan Field Dependent. Tesis. Universitas Pattimura.

Ratumanan, T. Gerson. (2003). Pengembangan Model Pembelajaran Interaktif dengan Setting Kooperatif (Model PISK) dan Pengaruhnya terhadap Hasil Belajar Matematika Siswa SLTP di Kota Ambon. Disertasi. Universitas Negeri Surabaya.

Someren, V., Maarten, W.Y.F.B., \& Jacobijn A.C.S. (1994). The Think Aloud Method: A Practical Guide to Modelling Cognitive Processes. London: Academic Press.

Winkel, W.S. (1996). Psikologi Pengajaran. Jakarta: Gramedia.

Witkin, H.A., Moore, C.A., Goodenough, D.R., \& Cox, P.W. (1977). Field-Dependent and Field-Independent Cognitive Styles and Their Educational Implications. Winter 
Review of Educational Research, Vol. 47 No. 1.

Zuhri, D. (1998). Proses Berpikir Siswa Kelas 11 SMPN 16 Pekanbaru Dalam Menyelesaikan Soal-Soal Perbandingan Senilai Dan Perbandingan Berbalik Nilai. Tesis. Surabaya: Pascasarjana UNESA. 